\title{
わが国における学校環境衛生の管理
}

\author{
北垣邦彦
}

\section{Management for School Environmental Health in Japan}

\author{
Kunihiko Kitagaki ${ }^{\dagger}$ \\ School Health Education Division, Ministry of Education, Culture, Sports, Science and \\ Technology; 3-2-2 Kasumigaseki, Chiyida-ku, Tokyo 100-8959, Japan.
}

(Received November 10, 2015)

\begin{abstract}
Some acts such as the Basic Environment Act are aimed at managing environmental health for a productive living environment in Japan. School is not only a place where lessons for a better future are taught but also an environment in which children spend many hours of their day. Therefore, activities involving regular checks are important to maintain and improve the school environment. Article 5 of the School Health and Safety Act states that schools must make plans and carry out regular checks on school environmental health. Article 6 prescribes that the Minister of Education, Culture, Sports, Science and Technology establish a "school environmental health standard". This standard involves metrics on the classroom environment (quality of air, illumination, and noise levels), quality of drinking/pool water and so on, and their standard values and evaluation methods. Article 23 prescribes that each school except colleges/ universities have a school pharmacist. The school pharmacist plays an important role in maintaining and improving the school's environmental health. However, the current actions taken are not adequate. Therefore, prospects for future activities will be discussed based on the current situations and problems.
\end{abstract}

Key words $—$ School Health and Safety Act; environmental health; school pharmacist

\section{1. はじめに}

わが国では，生活環境の衛生管理の観点から「環 境基本法」を始めとする様々な法律がある. 子供た ちにとつて学校は，学びの場であるだけでなく，1 日のうち多くの時間を過ごす生活の場でもある。し たがって, 学校の環境を衛生的に保持し, 必要に応 じて改善を図ることは重要である.

平成 20 年 1 月 17 日に公表された中央教育審議会 の答申「子どもの心身の健康を守り, 安全・安心を 確保するために学校全体としての取組を進めるため の方策について」1)では，学校環境衛生検査がかな らずしも完全に実施されていない状況があることか ら，法制度の整備を検討することが求められた。学 校保健法等の一部を改正する法律（平成 20 年 6 月

文部科学省スポーツ・青少年局学校健康教育課 (下1008959 東京都千代田区霞が関 3-2-2)

現所属: †東京薬科大学薬学部社会薬学研究室（T1920392 東京都八王子市堀之内 1432-1)

e-mail: kitagaki@toyaku.ac.jp

本総説は, 日本薬学会第 135 年会シンポジウムS58 で 発表した内容を中心に記述したものである.
18 日法律第 73 号）により「学校保健法（昭和 33 年法律第 56 号)」が「学校保健安全法」に名称が変 わり平成 21 年 4 月 1 日から新たに施行されてい る。学校保健安全法では, 答申を踏まえ学校環境衛 生の維持・管理に関して新たな規定が加えられてい る.

\section{2. 学校における環境衛生検査の現状}

2-1. 学校保健の目的学校保健安全法では, 学校保健の保健管理を「学校の管理運営等」,「健康 相談等」,「健康診断」, 「感染症の予防」, 「学校保健 技師並びに学校医, 学校歯科医及び学校薬剤師」, 「地方公共団体の援助及び国の補助」に分けて規定 している. 児童生徒等の健康管理と学校の環境管理 に分けて考えることもできる，学校の衛生環境は児 童生徒等の健康及び学習能率等に大きな影響を及ぼ すことがあることから，学校の環境を衛生的に保持 し, 必要に応じて改善を図るための環境衛生検査等 の学校環境衛生活動が重要になる.

近年, 学校保健の対象となる課題は, 多様化・複 雑化してきており, 専門的な知識や経験が必要とな 
Table 1. "School Health and Safety Act"

学校保健安全法

第 5 条 (学校保健計画の策定等)

児童生徒等及び職員の心身の健康の保持増進を図るため, 児童生徒等及び職員の健康診断，環境衛生検査，児童生徒

等に対する指導その他保健に関する事項について計画を策定し，これを実施しなければならない.

第 6 条 （学校環境衛生基準）（抜粋）

文部科学大臣は，学校における換気，採光，照明，保温，清潔保持その他環境衛生に係る事項に規定する事項につい

て, 児童生徒等及び職員の健康を保護する上で維持されることが望ましい基準（以下この条において「学校環境衛生基

準」という.）を定めるものとする.

2 学校の設置者は, 学校環境衛生基準に照らしてその設置する学校の適切な環境の維持に努めなければならない.

3 校長は, 学校環境衛生基準に照らし, 学校の環境衛生に関し適正を欠く事項があると認めた場合には, 遅滞なく, そ

の改善のために必要な措置を講じ, 又は当該措置を講ずることができないときは, 当該学校の設置者に対し, その旨を

申し出るものとする.

学校保健安全法施行規則

第 1 条 (環境衛生検査)（拔粋）

学校保健安全法第 5 条の環境衛生検査は, 他の法令に基づくもののほか, 毎学年定期に, 法第 6 条に規定する学校環 境衛生基準に基づき行わなければならない.

2 学校においては, 必要があるときは, 臨時に, 環境衛生検査を行うものとする.

第 2 条（日常における環境衛生）

学校においては, 前条の環境衛生検査のほか, 日常的な点検を行い, 環境衛生の維持又は改善を図らなければならない,

ることも少なくない. 学校保健が適切かつ円滑に実 施されるためには, 国, 教育委員会等の学校設置者 及び学校薬剤師を含む教職員のそれぞれが重要な役 割を担つている.

2-2. 学校保健安全法学校保健安全法及び学 校保健安全法施行規則（昭和 33 年 6 月 13 日文部省 令第 18 号）における学校環境衛生の維持・管理に 関連する規定は, Table 1 の通りであり, 国, 設置 者及び校長の責務が示されている.

以上をまとめると, 学校は, 学校保健計画に環境 衛生検査の実施時期を記載し, 学校環境衛生基準 (平成 21 年 3 月 31 日文部科学省告示第 60 号) に示 される検査項目を定められた回数及び方法で実施す る必要がある。また, 環境衛生検査の結果, 学校環 境衛生基準に示される基準を逸脱していた場合に は, 速やかな改善が求められている.すなわち, 学 校における環境衛生の維持・管理の状況を把握する ためには，環境衛生検査の実施状況のみならず，基 準の逸脱の有無及び逸脱していた場合には改善状況 等について把握する必要がある.

文部科学省では，「学校環境衛生基準」の内容を 踏まえ, 学校における環境衛生検査及び日常におけ る環境衛生に関する点検の円滑な実施の一助となる よう，検査方法の詳細や留意事項等を示した「[改 定版］学校環境衛生管理マニュアル 〜「学校環境
衛生基準」の理論と実践〜」(平成 22 年 3 月) ${ }^{2}$ を 全国の国公私立の幼稚園, 小学校, 中学校, 高等学 校, 中等教育学校, 特別支援学校, 大学及び高等専 門学校等に配布している。 また, 文部科学省ホーム ページからダウンロード可能である.

2-3. 環境検査の実施状況学校における環境 衛生検查の実施状況については, (公社) 日本薬剂 師会学校薬剂師部会により毎年調查項目を変えて実 施されており,「全国学校保健調査」として取りま とめられている。平成 25 年度はプールの水質や施 設設備, 平成 26 年度は換気, 温度・湿度等の空気 環境についてであった.

プールの水質検査（定期検査）は使用日 30 日毎 に 1 回以上の実施であり, 基準通りに実施した学校 の割合は $86.9 \%$ であた。多くの学校において適 切に実施されていたが，検査項目によって実施率が 大きく異なり, 実施状況に改善が求められるものが あることも示唆された. なお，検査の結果，基準に 適合していない項目があった学校はおよそ 10 校に 1 校であったが，そのほとんどが学校薬剤師等の指 導助言により改善が認められていた。

一方, 平成 26 年度に実施された換気, 温度・湿 度等の空気環境の検查実施状況を見ると, 項目別に 実施率が異なるだけでなく, プールの水質検査と比 較すると適切に実施されていない状況が窥える。換 
Table 2. Enforcement Regulations of "School Health and Safety Act"

学校保健安全法施行規則 (抜粋)

第 24 条 (学校薬剤師の職務執行の準則)

学校薬剤師の職務執行の準則は，次の各号に掲げるとおりとする.

(1) 学校保健計画及び学校安全計画の立案に参与すること.

（2）第一条の環境衛生検査に従事すること.

（3）学校の環境衛生の維持及び改善に関し，必要な指導及び助言を行うこと.

(4) 法第八条の健康相談に従事すること.

（5）法第九条の保健指導に従事すること.

（6）学校において使用する医薬品, 毒物, 劇物並びに保健管理に必要な用具及び材料の管理に関し必要な指導及び助言 を行い, 及びこれらのものについて必要に応じ試験, 検査又は鑑定を行うこと.

（7）前各号に掲げるもののほか, 必要に応じ, 学校における保健管理に関する専門的事項に関する技術及び指導に従事 すること。

気（二酸化炭素）以外は不適合項目のある学校の割 合が低い。しかし，極めて健康影響が大きい一酸化 炭素において不適合が見つかっている（1.0\%）に もかかわらず，改善状況が分からないと回答した学 校の割合がおよそ 5 校に 1 校もある. 検査項目実施 目的や対象となっている物質等の毒性など専門的な 知識が不足していると考えられ, 学校薬剤師等の専 門家の指導・助言の充実が求められる.

\section{3. 学校環境衛生活動における学校薬剤師の役割}

3-1. 学校薬剤師の職務執行の準則学校保健 安全法第 23 条では, 大学以外の学校には, 学校薬 剂師を置くものとするとされ, その職務は保健管理 に従事することである。その詳細は, 学校保健安全 法施行規則において定められている（Table 2).

3-2. 学校保健と環境教育環境と人間との係 わりは, 双方向性であり, 人間の健康は, 個人を取 り巻く環境から深く影響を受けている。したがつ て, 学校保健の観点から健康を保持増進するために は，心身の健康に対する環境の影響について理解で きるようにする必要がある. 体育科・保健体育科で は衛生管理に不備があると健康被害が生じることが あることを学ぶことになっており, 保健教育を通じ て保健管理の大切さの認識を向上できると考えてい る.

例えば，中学校保健体育科で学ぶ「飲料水や空気 の衛生的管理」は，学校における環境衛生検査に深 く関連している. 飲料水の水質は, いくつかの物質 について一定の基準が設けられている。学校におい ては, 日常的に味, 色, 臭いなど感覚的な点検以外 にも遊離塩素濃度を測定している. なぜ，日常的に
測定する必要があるかについて考察することによつ て，一見きれいに見える水が飲料水としてかならず しも適さないこともある理由や飲料水としての適否 は, 科学的な方法によって検査し, 管理する必要が あることについて理解が深まると考える。学校環境 衛生活動を題材として保健教育に取り入れることを ねらいとした実践事例集「学校環境衛生活動を生か した保健教育 〜小・中・高等学校で役立つ実践事 例集〜」3) が(公財) 日本学校保健会から作成されて おり，ホームページにて内容を見ることができる.

3-3. 健康相談 ·保健指導近年, 環境が関連 する健康影響に対する坚童生徒・保護者・教職員の 疑問や不安への対応など学校においても現代的な健 康課題が山積している。学校保健安全法施行規則の 改正では学校薬剂師の職務として新たに「健康相談」 及び「保健指導」が加えられ，このような健康課題 に対しても学校薬剤師の積極的な関与が期待されて いる. 例えば, 微小粒子状物質 (PM2.5)について, 環境省の専門家会合は注意喚起のための暫定的な指 針值を 1 日平均值 $70 \mu \mathrm{g} / \mathrm{m}^{3}\left(1\right.$ 時間平均值 $\left.85 \mu \mathrm{g} / \mathrm{m}^{3}\right)$ とすることなどを示した報告書4) 平成 25 年 2 月 27 日にとりまとめた。しかし，学校現場では，暫 定的な指針值付近の屋外活動の可否や小児を含む高 感受性者への注意の程度などについて混乱が生じ た。その後,「微小粒子状物質（PM2.5）に関する よくある質問 $(\mathrm{Q} \& \mathrm{~A})\rfloor^{5)}$ が作成され，混乱がなく なってきた．学校薬剤師は，このような資料を参考 として教職員や保護者に対して専門家の視点を伝え る保健指導等に役立てて頂きたい. 


\section{4. おわりに}

学校保健については，日常大きな問題がないこと が当然である. しかし，この当然の状態を作り上げ るためには日々の努力の継続と関係者・関係機関の 連携が不可欠である. しかし, 学校における学校保 健の担当者は限られており，学校環境衛生に関する 問題に対する認識が低い現状がある。また，問題意 識があっても学校内や担当者で問題を抱え込んでい るかもしれない。学校薬剂師は, 学校をサポートす る専門家や専門機関等が身近にあることを学校や担 当者に伝えてほしい。

さらに，これまでは薬科大学 (薬学部) 及び薬学 会等の薬学専門機関は，環境衛生分野については基 礎研究を通じた社会への貢献が主であったかもしれ ないが，今後は基礎を現場で実践している学校薬剤 師やその関係団体等への学術的な支援を充実して頂 けることを期待している.

子供たちの生活の場でもある学校の生活環境を安 全で安心できるものにすることが，すべての学校教 育活動の基盤であると考える，その基盤を整えるた めに関係者の再確認が求められている.

利益相反＼cjkstart開示すべき利益相反はない.

\section{REFERENCES}

1) Central Council for Education. "Kodomo no Shinshin no Kenko wo Mamori, Anzen/Anshin wo Kakuho surutameni Gakkozentai toshiteno Torikumi wo Susumeru tameno Hosaku ni tsuite," 2008.

2) Ministry of Education, Culture, Sports, Science and Technology. "[Kaiteiban] Gakkokankyoeiseikanri manual - 'Gakkokankyoeiseikijun' no Riron to Jissen-,' 2010: / http: // www.mext.go.jp / a _ menu / kenko/hoken/1292482.htm $\rangle$, cited 24 August, 2015.

3) Japanese Society of School Health. "Gakkokankyoeiseikatsudo wo Ikashita Hokenkyoiku - Sho/Chu/Kotogakko de Yakudatsu Jissenjireishu — ,' 2014: 〈 http: // gakkohoken.jp/book/ebook/ebook_H260010/index.html\#4〉, cited 24 August, 2015.

4) Ministry of the Environment. "Bisho Ryushijo Busshitsu (PM2.5) ni kansuru Joho: Senmonka Kaigi Hokokusho.": 〈http://www. env.go.jp/air/osen/pm/info/rep_20130227. html $\rangle$, cited 24 August, 2015.

5) Ministry of the Environment. "Bisho Ryushijo Busshitsu (PM2.5) ni kansuru Yokuaru Shitsumon (Q\&A).": 〈http://www.env.go. jp/air/osen/pm/info/attach/faq.pdf $\rangle$, cited 24 August, 2015. 